\title{
Glycerin Purification of Biodiesel Production Side Products by Distillation Method
}

\author{
*Mohammad Istnaeny Hudha \\ Chemical Engineering Department \\ National Institute of Technology (ITN) \\ Malang, Indonesia \\ istnaeny.hudha@lecturer.itn.ac.id
}

\author{
Dimas Indra Laksmana \\ Industrial Engineering Department \\ National Institute of Technology (ITN) \\ Malang, Indonesia
}

\begin{abstract}
Limited reserves of fossil fuels in the world, encouraging each country, the search for alternative energy sources is more urgent. One alternative to renewable energy is biodiesel produced from vegetable oil. Biodiesel is generally produced from the transesterification process of vegetable oils (triglycerides) and methanol with the help of alkaline or acidic catalysts. The biodiesel transesterification process will produce the main by-product of crude glycerin (glycerol), with an amount of about $10 \%$ by weight of the biodiesel product. With the rapid growth of the biodiesel industry, glycerin production has become a surplus. The glycerin crude produced in the manufacture of biodiesel contains a lot of methanol, KOH catalyst, soap, potassium, water and other substances. These impurities must be separated from glycerin so that they can be used and processed into other more valuable products. The process of separating the dirt can be done in various ways. One way of purifying glycerin is by acidification using acid. The salt deposits resulting from the acidification reaction are then separated between glycerin and its sediment. The glycerin obtained is then refined by the distillation method. From the results of the study obtained the highest glycerin purity of $90 \%$
\end{abstract}

Keywords - crude glycerine, acidification, distillation

\section{INTRODUCTION}

\section{A. Background}

The depletion of fossil fuel reserves encourages the search for alternative energy sources. Biodiesel produced from vegetable oil is one of the leading alternatives to be explored to reduce global dependence The depletion of fossil fuel reserves encourages the search for alternative energy sources. Biodiesel produced from vegetable oil is one of the superior alternatives to be explored to reduce global dependence on fossil fuels

Biodiesel is generally produced from transesterification of vegetable oils (triglycerides) and methanol with the help of alkaline or acidic catalysts. The biodiesel transesterification process produces glycerin (glycerin) crude as the main by-product, with an amount of about $10 \%$ by weight of the biodiesel product. The rapid growth of the biodiesel industry worldwide, resulting in surplus glycerin production. It is estimated that in 2018 it is estimated that the world's crude glycerin production will reach 36 billion liters [1]. At present, Indonesia has a biodiesel industrial production capacity of 4 million KL / year, so that around 400,000-600,000 tons / year of glycerin crude will be produced [2]. Thus, glycerin utilization has become a serious issue in the biodiesel industry. The use of glycerin can be an increase in economic value added for the sustainability of the biodiesel industry. In addition, the conversion of glycerin is expected to avoid the occurrence of environmental problems due to glycerin emissions[3].

Glycerin crude has a purity of between $15-50 \%$ and contains a number of contaminants such as water, methanol, soap / free of fatty acids (FFA), salts, and unused reactants. In order to be utilized in various industries and increase its selling value, it is very important to purify crude glycerin. High purity glycerin (80-90)\% can be used as raw material for various industrial applications in food, cosmetics and pharmaceutical industries. The pure glycerin price (Technical grase, 99\%) currently in the market has a price of around Rp. 30,000 per kilogram so that glycerin is one of the products with high economic value..

Purifies glycerin by using hydrochloric acid to a $\mathrm{pH}$ of around 4.5 [4]. As a result the soap becomes fatty acids and salt. The fatty acids will be separated in the upper layer, while the remaining methanol can be taken through the evaporation process. This process can increase the purity of glycerin from $50 \%$ to $80 \%$.

Purify glycerin by neutralizing base catalysts and breaking soap into fatty acids and salts using some strong acids such as $36 \% \mathrm{HCl}, 40 \% \mathrm{H}_{2} \mathrm{SO}_{4}$ and $85 \% \mathrm{H}_{3} \mathrm{PO}_{4}$ at 60 $0 \mathrm{C}$ and $\mathrm{pH} 4.5$ [5]. The results were obtained by glycerin with a purity of $78-82 \%$ using $85 \% \mathrm{H}_{3} \mathrm{PO}_{4}$.

This research is a follow-up study to purify glycerin produced from the acidification process of three types of acid namely sulfuric acid, nitric acid and phosphoric acid with a number of moles of $36 \mathrm{mmol}$ with a $\mathrm{pH}$ of 4.5 . Glycerin obtained is then refined by distillation method.

\section{B. Literature review}

Biodiesel is an alkyl ester compound resulting from simple transesterification of triglycerides and alcohol, with glycerin by-products. After transesterification is complete, most $\mathrm{KOH}$ will be separated from methyl esters with glycerin. The use of $\mathrm{KOH}$ as a catalyst because it has many advantages compared to other base catalysts. The advantages in separating methyl esters with glycerin and in relation to their reaction with mineral acids produce potassium salts which can be used as fertilizer.

Glycerin is an alcohol compound which has 3 hydroxyl groups, with the standard name 1,2,3-propanetriol. This compound is liquid, colorless with a boiling point of $290 \mathrm{oC}$. The high boiling point of the compound with a molecular weight of $92.09 \mathrm{~g} / \mathrm{mol}$ is due to the presence of a very 
strong hydrogen bond between the glycerin molecules. Glycerin is also a raw material for the formation of triglycerides, which can form ester bonds with fatty acids. Various studies on glycerin continue to be developed to increase the added value of crude glycerin (whose composition is $33 \%$ consisting of water and catalyst residues) biodiesel production residues

Purification needs to be done on glycerin. Purification begins with the addition of acid to neutralize alkaline catalyst residues and break down soap into free fatty acids and salt [6]. Base neutralization with acids is an exothermic reaction. The addition of acids is carried out little by little in a constantly stirring state so that the heat released does not occur suddenly and simultaneously in large numbers (explodes).

Alkaline neutralization and breakdown of soap produce salt, water, and free fatty acids. Solubility of salt in glycerin and methanol is very low. Much salt settles in the glycerin layer. Water and residual methanol are more easily dissolved in the glycerin layer. Free fatty acids are not soluble in glycerin and form a separate layer above the glycerin layer. Soap can cause emulsions between glycerin and free fatty acids so it is difficult to separate. The separation between the glycerin layer and free fatty acids takes place perfectly after all the soap is broken down into salt and free fatty acids. This causes glycerin to be acidic or have a $\mathrm{pH}$ of $<7$ [7].

The purification of glycerin byproducts of biodiesel made from used cooking oil with the addition of 5\% phosphate acid in dirty glycerin causes the formation of 2 layers, the upper layer is free fatty acid, the remaining methanol and potassium phosphate deposits, the lower layer is glycerin. The addition of this acid aims to attract potassium ions contained in dirty glycerin and change the soap formed in the reaction of making biodiesel, to free fatty acids [8].

\section{MAterial AND Methods}

This research was conducted with the experimental method and data analysis through graphs. Where this research activity was conducted at Analyst Chemistry Laboratory of Chemical Engineering ITN Malang.

\section{A. Research Materials and Tools}

The material used in this study is glycerin byproduct of palm oil biodiesel production, sulfuric acid $96 \%$, nitric acid $65 \%$ and phosphorus acid $85 \%$ and aquadest. While the materials used for analyzing glycerin include $\mathrm{NaIO} 4$, ethylene glycol, BTB $0.4 \%$ indicator, $\mathrm{HCl}$ standard solution $0.01 \mathrm{~N}, \mathrm{PP}$ indicator $1 \%, \mathrm{KOH}$ standard solution 0.1 $\mathrm{N}$, as for the required equipment including thermometers, condensers, hot magnetic stirrer plates, and other laboratory equipment such as three-neck pumpkins, erlenmeyer flasks, measuring flasks, measuring flasks, cup goblets, burettes, separating funnels, stirrers, saucers, desiccators, portable balance and analytical balance.

\section{B. Research Methods}

Crude glycerin used in this purification process is glycerin byproduct of biodiesel production. Crude glycerin with a content of about $20.72 \%$, then heated at a temperature of 60
${ }^{0} \mathrm{C}$ and added acid (85\% phosphoric acid, 96\% sulfuric acid and $65 \%$ nitric acid) as much as $36 \mathrm{mmol}$ little by little while stirring continuously, followed by stirring with using a magnetic stirrer at $400 \mathrm{rpm}$ for 30 minutes. The solution formed is then allowed to stand for 30 minutes. The next stage of the acidified glycerin is separated by its sediment and analyzed for glycerin levels. The flow chart for preparation and analysis of samples and the process of purifying glycerin by distillation method are presented in the following figure:

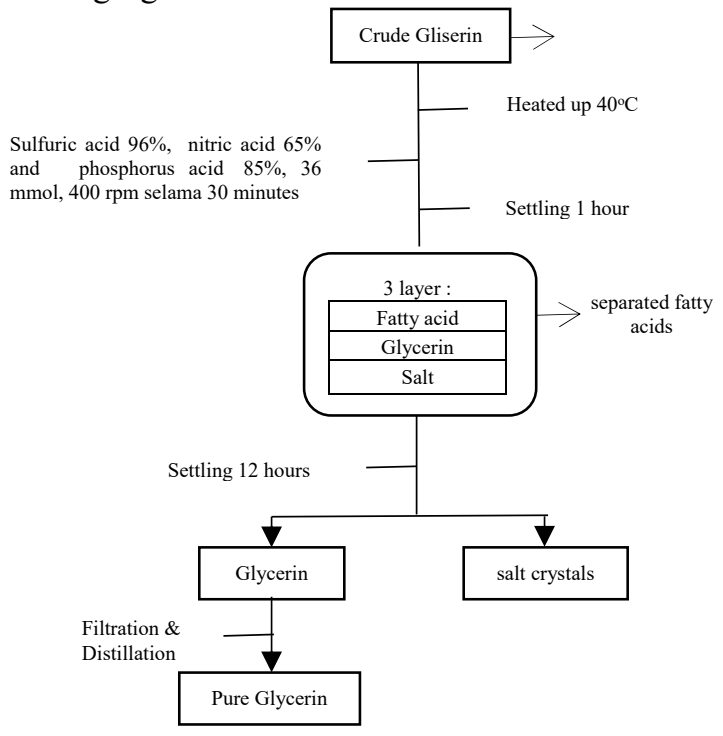

Fig. 1. Research framework for glycerin purification by distillation

\section{RESULT OF RESEARCH AND DISCUSSION}

Another component of purification of crude glycerin byproducts of biodiesel production with a purity of about $50 \%$ in the form of blackish brown viscous liquid with a $\mathrm{pH}$ above 10 , crude glycerin consisted of glycerin $(50-60) \%$, alkali in the form of soap and hydroxide catalyst (15-18)\%, methanol (8-12)\%, water (2-3)\% and other components.

The glycerin used in this study is from the results of the palm oil transesterification process into biodiesel. Crude glycerin still contains a lot of impurities and has not been purified so the added value is still low. The impurities contained in the glycerin can be residual methanol, residual catalysts, and other impurities derived from biodiesel feedstock oil. Crude glycerin that is cured has a low level of around $20-30 \%$; Because the purity of crude glycerin obtained is still quite low, it is necessary to purify the process to increase the level of glycerin purity and eliminate unwanted impurities. One way is to add acid so that it is expected to increase glycerin levels

The results of the analysis of crude glycerin in this study can be seen in table 1 below:

TABLE I. RESUlTS OF ANALYSIS OF BIODIESEL SIDE GLYCERIN ANALYSIS FROM PALM OIL

\begin{tabular}{|l|r|}
\hline \multicolumn{1}{|c|}{ Type of Analysis } & \multicolumn{1}{|c|}{ Result } \\
\hline $\mathrm{Ph}$ & 11,36 \\
\hline Level of $\mathrm{KOH}$ & $6,1261 \%$ \\
\hline Soap Content (in K-Palmitat) & $11,6807 \%$ \\
\hline
\end{tabular}


$\mathrm{pH}$ test shows that glycerin byproduct of palm oil biodiesel has a $\mathrm{pH}$ of 11.36. The level of acidity $(\mathrm{pH})$ of glycerol shows its alkaline nature. This is due to the content of $\mathrm{KOH}$ and potassium soap. Ionization of $\mathrm{KOH}$ and potassium soap in water will produce hydroxyl ions $(\mathrm{OH}-)$.

Analysis of glycerin by-products of biodiesel from palm oil showed KOH levels of $6.1261 \%$ (b / b). This shows that in $50 \mathrm{~g}$ there is $3.0631 \mathrm{~g} \mathrm{KOH}$. And K-palmitate content was $11.6807 \%(\mathrm{~b} / \mathrm{b})$. This shows that in $50 \mathrm{~g}$ of material there are 5,8404 $\mathrm{g}$ of $\mathrm{K}$-palmitate. Potassium soap is a salt formed from fatty acids with a potassium base. Ionizing potassium soap in water produces hydroxyl ions and is alkaline.

The acidification process is carried out by reacting crude glycerin with acid (sulfuric acid, phosphoric acid and nitric acid) as much as $36 \mathrm{mmol}$ to separate glycerin with impurities in the form of fatty acids and salt. As an illustration, if the acid that we use is phosphoric acid, then phosphoric acid will react with the rest of the catalyst potassium hydroxide $(\mathrm{KOH})$ to form a crystalline potassium phosphate salt that settles in the lowest layer. While the upper layer will form free fatty acids resulting from the hydrolysis reaction between the remaining triglyceride oil and water. The reaction is as follows :

\begin{tabular}{|c|c|c|c|}
\hline \multicolumn{4}{|c|}{$3 \mathrm{KOH}+\mathrm{H}_{3} \mathrm{PO}_{4}$} \\
\hline Catalist & phosphoric acid & Salts & Water \\
\hline
\end{tabular}

Glycerin purification from acidification by distillation method can be seen in the following table 2

TABLE II. GLYCERIN LEVELS AFTER TREATMENT

\begin{tabular}{|c|c|c|}
\hline \multirow{2}{*}{ Type of acid } & \multicolumn{2}{|c|}{ Level Gliserin (\%) } \\
\cline { 2 - 3 } & acydification & distillation \\
\hline $\begin{array}{c}\text { sulfuric acid } 96 \% \\
\left(\mathrm{H}_{2} \mathrm{SO}_{4}\right)\end{array}$ & 64,00 & 69.52 \\
\hline $\begin{array}{c}\text { phosphoric acid } 85 \% \\
\left(\mathrm{H}_{3} \mathrm{PO}_{4}\right)\end{array}$ & 64,00 & 90,00 \\
\hline $\begin{array}{c}\text { nitric acid } 65 \% \\
\left(\mathrm{HNO}_{3}\right)\end{array}$ & 42,82 & 77,04 \\
\hline
\end{tabular}

Determination of glycerin levels was carried out to show the level of purity of glycerin expressed in percent. The method used to determine glycerin levels according to SNI 06-1564-1995 is an alkalimetry method. Based on Table 2 above, it is known that there is a significant increase in glycerin levels. This shows that the distillation method is effective enough to purify glycerin by separating water and methanol to produce higher glycerin levels.

\section{CONCLUSION}

Based on the results of the study it can be concluded that the purification of glycerin by acidification reaction using acid genes (sulfuric acid, phosphoric acid and nitric acid) as much as $36 \mathrm{mmol}$ followed by purification using distillation is quite effective, with the highest yield of glycerin levels of $90 \%$

\section{ACKNOWLEDGMENT}

On this occasion, the author expressed his gratitude to the Minister of Research and Technology of Higher Education for funding this research. We also thank you to ITN Malang as the Institution where researchers are domiciled, which provides support for facilities and infrastructure, the Chemical Engineering Study Program who have facilitated this research

\section{REFERENCES}

[1] Nanda MR, Yuan Z, Qin W, Poirier M, Chunbao X, Purification Of Crude Glycerol Using Acidification: Effects Of Acids Types And Product Characterization, Austin Journal of Chemical Engineering, 2014.

[2] Javani A, Hasheminejad M, Tahvildari K, Tabatabaei M, "High Quality Potassium Phosphate Production Through Step-By-Step Glycerol Purification: A Strategy To Economize Biodiesel Production, Bioresour Technol", vol 104, 2012, pp. 788-790

[3] Setyaningsih Dwi, Hambali, E., Farobie O., Pembuatan Pupuk Potassium Dari Proses Pemurnian Gliserin Hasil Samping Industry Biodiesel, Konferensi Nasional, 2007.

[4] Gerpen, J.V., Business Management for Biodiesel Producer, Subcontractor Report NREL : Iowa State University, 2004.

[5] Kocsisová, T. dan J. Cvengroś, "G-Phase form Methyl Ester Production-Splitting and Refining", Petroleum \& Coal, vol. 48 (2), 2006, pp. $1-5$.

[6] Gerpen, J.V., "Biodiesel Processing and Technology", Fuel Processing Technology, vol. 86, 2005, pp. 1097 - 1107.

[7] Fanani, Study of The Purification of Glycerin Byproducts of Jarak Pagar Using Nitric Acid, Sulfate and Phospate (Kajian Pemurnian Gliserin Hasil Samping Biodiesel Jarak Pagar Menggunakan Asam Nitrat, Sulfat, dan Fosfat), Essay Unpublished, Faculty of Agricultural Technology, Bogor Agricultural Institute, 2008.

[8] Aziz, I., Siti Nurbayti, Fira Luthfiana, Purificaion of Glycerin From The Byproducts of Making Biodiesel Using Raw Materials of Used Cooking Oil (Pemurnian Gliserin dari Hasil Samping Pembuatan Biodiesel Menggunakan Bahan Baku Minyak Goreng Bekas), Valensi, Vol. 1 No. 3, 2008, pp. 157-162. 